Journal of Social Sciences 7 (1): 76-89, 2011

ISSN 1549-3652

(C) 2010 Science Publications

\title{
Social and Environmental Accounting Education and Sustainability: Educators' Perspective
}

\author{
Norhayah Zulkifli \\ Department of Financial Accounting and Auditing, \\ Faculty of Business and Accountancy, University of Malaya, 50603 Kuala Lumpur
}

\begin{abstract}
Problem statement: It is asserted that any attempt to account for sustainability will need to reflect the tensions which exist between conventional accounting with its record of wealth accumulation and its focus on the pursuit of profit and the demands for a just and equitable society. Consequently, the argument that the current accounting education is deficient in promoting ethical awareness, of which social and environmental concerns are a part, has given rise to the advocating of the learning of Social and Environmental Accounting (SEA). This study intends to determine the perspectives of accounting educators in Malaysia towards the elements and roles of SEA and the relevance and importance of studying SEA. In addition it intends to determine the perceptions of accounting educators towards the orientation of the traditional approach of accounting education. Approach: 222 survey questionnaire respondents consisting of accounting educators from the public and private Institutions of Higher Learning (IHL) in Malaysia that offer accounting programs are involved. Results: This study recognises the positive reception by the accounting educators in Malaysia to the elements embodied by SEA which promotes the development of moral and ethical awareness of accounting students towards corporate behaviours, society and the environment. It advocates a formal approach of SEA education in the IHL as the appropriate means of enhancing social and environmental awareness and the inculcation of ethical values. Conclusion: The findings suggested the necessity to develop SEA education as an alternative approach to teaching accounting in the IHL in Malaysia.
\end{abstract}

Key words: Social and environmental accounting, accounting education, Social and Environmental Accounting (SEA), accounting educators, ASEAN

\section{INTRODUCTION}

In 1987, the United Nations Commission on Environment and Development (the Bruntland Commission) drew attention to the fact that economic development often leads to deterioration, not improvement, in the quality of people's lives. The Commission, therefore, called for 'a form of sustainable development which meets the needs of the present without compromising the ability of future generations to meet their own needs' (United Nations World Commission on Environment and Development, 1987 p.8). There are two fundamental issues. Firstly, development is not just about bigger profits and higher standards of living for a minority. It should be about making life better for everyone. Secondly, development should not involve the destruction or the irresponsible exploitation of the natural resources, nor should it engage in environmental pollution.

The neo-liberal view represented by the proponents of environmental accounting consider air, water, soil and other environmental elements as 'natural capital' which has to be preserved intact or renewed. They maintain that if this is not done, such capital will diminish. By assigning values to this capital and using classical economic criteria, the incomes from particular courses of development can be measured against the corresponding depletion of capital. Consequently, projects embarked with a conscious consideration of potential environmental costs and benefits will ensure that long run sustainable development is achieved. In the area of waste discharge, for example, this principle has now been applied. The ongoing discussions and proposals on atmospheric pollution regulation have also seen the incorporation of the same principle. Despite these advances and the considerable interest that has been generated among economists over the possibility of incorporating environmental values in accounting procedures, the same proponents of environmental accounting are quick to acknowledge the significant difficulty in providing a valuation of 'natural capital.' This valuation problem becomes all the more 
complicated since it would need to take into account the value of resources to future generations whose livelihood and consumption patterns are unknown.

The definition of sustainability as provided by United Nations World Commission on Environment and Development (1987) encompasses both meeting the needs of the world's poor population and maintaining environmental resources for the future. The possible meanings and contradictions inherent in the term sustainability extend to the concept of sustainable development. Thus, according to Bebbington (1997, 2001), the definition of what constitutes a "sustainable society" becomes under-specified. According to Bebbington, the key structural question ingrained in sustainable development appears to be how to manage the economic systems such that development (under a revised definition) takes place without damaging the environment, on which all present and any future development rests. In this regard, it is asserted that accounting plays a vital supporting role in the creation and perpetuation of the current economic order (Hines, 1988; Tinker, 1991). Given this, any attempt to account for sustainability will need to reflect the tensions which exist between conventional accounting with its record of wealth accumulation and its focus on the pursuit of profit and the demands for a just and equitable society.

In this connection, the study takes into cognisance the concerns of Social and Environmental Accounting (SEA) advocates and people from the accounting fraternity with the inadequate state of accounting education in keeping abreast with changes, particularly those pertaining to social and environmental responsibilities (Lewis et al., 1992). As a relatively new body of knowledge in accounting, disseminating SEA through SEA education is considered appropriate and timely (Bebbington, 1995; Mathews, 1995; Owen, 2004) and it is a contention of many experts that this education can provide the solution to the ethical issues that already beset the profession (Gray et al., 1994).

As far as Malaysia is concerned, it is a developing country with an impressive economic growth track record during the 1990s and as indicated by the $9.8 \%$ points rise in the Malaysian Quality of Life Index (MQLI), its quality of life has continued to improve from 1990-2002 (Economic Planning Unit, Malaysia, 2005). The country is said to experience an exciting economic expansion at least around and within the ASEAN (Association of Southeast Asian Nations) region (Mahmood, 2002). This impressive growth is not without its pitfalls. While significant strides have been made in transportation, communication and the working life, for example, two other components of quality of life have deteriorated. These are public safety and the environment. Crime rate per thousand of population has increased from 3.8 per thousand people in 1990- 6.2 in 2002. The relatively current information shows that there has been a $15 \%$ increase in the crime rate in Malaysia. In the first quarter of 2005, many cases of environmental degradation have hit the headlines of major local dailies, causing concerns on the part of the public and the government. Reports on illegal logging, hill cutting, river pollution, marine pollution, air pollution, improper treatment and disposal of toxic waste, deterioration of water quality, declining coral reefs, coastal erosion, over-fishing and biodiversity loss are fast becoming a norm. The rapid increase in the number of motor vehicles, urbanisation and industrial growth have all contributed to the deterioration in the quality of air and water. Clearly, growth has its own attendant social and environmental problems.

Linking the social and environmental problems, sustainability issues, the argument that the current accounting education is deficient in promoting ethical awareness, of which social and environmental concerns are a part and in response to the calls by various quarters for students to acquire a broader conception of accounting (Accounting Education Change Commission, 1990), this study is an attempt at determining the perspectives of accounting educators in Malaysia towards the elements and roles of SEA and the relevance and importance of studying SEA as well as determining accounting educators' perceptions towards the orientation of accounting education as it is conventionally approached.

Literature review: Current accounting education is said to be deficient in addressing pressing issues of ethics and professionalism and it has had its fair share of criticisms (Zeff, 1989; Kelly et al., 1999; Ferguson et al., 2005). Regarded by some as thoroughly deficient (Zeff 1989; Albrecht and Sack, 2000), too technically focused (Bebbington, 1995; Paisey and Paisey, 2000), neo-classical economic oriented (Tinker, 1980; Lewis et al., 1992), ethically insufficient (Huss and Patterson, 1993; Gray et al., 1994) and professionally inapt (Gray et al., 2001; Wyatt, 2004), it also receives scathing remarks in recent years from within the ranks of its own accounting fraternity (see for example Owen et al., 1994; Collison et al., 2000). Albrecht and Sack (2000), for example, believe that accounting education has failed both in developing the critical thinking skills of accounting students and in dealing with 'values, ethics and integrity'. In yet another assertion, Bebbington (1995) claims that the accounting education process has overly emphasised the technical aspects of accounting 
data and has presumptuously assumed that it operates in a neutral manner.

It would appear that the basis of much of the aforementioned criticisms can be traced to the inherent vocationally oriented nature of accounting education (Paisey and Paisey, 2000). In contrast, SEA requires a much broader concept of accounting (Mathews, 1994; Gray et al., 1996), one which embraces the idea of identifying explicitly social costs and social benefits in the decision-making process of companies (Mobley, 1970; Churchman, 1971; Linowes, 1972). In words more pertinent, Seidler (1975) and Bloom and Heymann (1986) report that the idea of social and environmental responsibility in accounting is partly due to an increased tendency to question the established order of society as well as a growing concern with the deterioration of the environment.

While there has been a proliferation of accounting literature relating to SEA (Mathews, 1994; Owen, 2004; Parker, 2005) in recent years and the corollary interest in CSD (corporate social disclosure) practices of companies, the focus on education has been somewhat peripheral in nature (Owen et al., 1994; Gibson, 1997). Lockhart and Mathews (2000) assert that the required changes in accounting education to complement the development of environmental accounting have not been vigorous enough. This apparent chasm between the academia and the realities "out there", is aptly summarised by Stevenson (2002), 'with the relatively high profile accorded to social and environmental issues over the past ten years, the weighting attached to SEA in university curricula may be seen as an illustration of the extent to which the teaching of accounting reflects changes in society'. Consequently, many writers are now calling on the accounting academia to rise and meet the changing needs of the society. One such call is voiced in the work by Gray et al. (2001). Outlining their wide interpretation of the meaning of environment, they justify the need for accounting training to consider environmental accounting education (Al-Rabaani and Al-Mekhlafi, 2009). Others see in an overhaul to the teaching of accountancy a means of not only advancing CSD as a natural subject matter to be included in the accounting discipline, but also a means of advancing the ethical and critical intellectual quality of the general education (Blundell and Booth, 1988; Lewis et al., 1992; Grinnel and Hunt, 2000; Lockhart and Mathews, 2000; Stevenson, 2002).

The conventional accounting system and policies are based on the paradigms implied by the classical economic theory of free markets, with the avowed emphasis on the role of private property and the use of the market mechanism to assign individual values (Bloom and Heymann, 1986; Gray et al., 1996). Accounting is thus subservient primarily to the interests of the financiers of a business enterprise. It provides business information that will help decisions to maximize profits of the financiers. It also checks on the stewardship of individuals entrusted by the financiers with the day to day running of the enterprise. In short, the main objective of the conventional model is maximization of the financiers' wealth in the secondary belief that society at-large too will benefit. Short term gains for the financiers are allocated well in advance of impacts on individuals, communities and the environment. Cooper and Sherer (1984) assert that conventional accounting stands as a political and social process that creates its own social reality-a reality that limits all possible interactions between the 'world' and the organization that it helped shape. While it is true that the decision usefulness and accountability theories do acknowledge the role of financial reporting as a decision making tool of various parties as well as a monitoring mechanism of the social performance of corporations (Henderson and Peirson, 1988), by and large, the literature on decision usefulness relates only to the needs of shareholders and creditors (Mathews and Perera, 1996).

As an important aspect of the free market system, corporate activities include the use of available "free goods', such as air and water, where the pollution effects are externalities rather than the internal costs of the enterprise (Gray et al., 1996). By "externalities", the economists refer to those consequences of an economic activity which are not reflected in the costs borne by the individual or organization benefiting from the said activity (Crowther, 2000). Accounting makes possible the functions of measuring and rectifying, among others, activities that seek profits, economic gains and the maximization of cash flow. By not taking into consideration, for instance, air and water pollution, which can be a consequence of some economic activities, accounting is guilty of not disseminating the full real account of the circumstances.

Since accounting is rooted in classical liberalism philosophy, it is inevitable that the discipline is only concerned with the measurement and reporting of activities that have a bearing on the individual firm. Any actions of the firm which have consequences beyond its confines are held not to be of its concern. Moreover, the free market mechanism operates by mediating between freely acting individuals to affect a kind of equilibrium that renders any fear by a particular 
firm of its actions upon externalities as irrelevant. As a consequence, such actions are deemed not a concern to be accounted for (Crowther, 2000). The cumulative effect of these basic values, definitions and principles and the technical nature of accounting mean that the effects of business decisions on individuals and communities cannot be recognized and environmental impact through externalities are defined out of existence (Mathews, 1994).

SEA is an attempt to fill the gap left open by conventional accounting. It deals with these 'externalities'. However, the actual measurement of external costs and benefits is extremely difficult and fraught with problems. This is one of the main obstacles to any form of SEA (Crowther, 2000). The evaluation of the performance of an organization is partly concerned with the measurement of performance and partly with the reporting of that performance. Accordingly, as mentioned by Crowther (2000), there should be a corresponding recognition of the need to change the measurement and reporting of a firm when a paradigm shift happens in favor of social accountability. Crowther (2000) contends further that power is the generally recognized essential component of accountability. Greater accountability is therefore accorded to those stakeholders who have more power. One of the problems with this is that the society at large and the environment in particular, do not constitute powerful stakeholders. It is perhaps for this reason that social accountability does not feature predominantly in organizations.

SEA transcends the traditional boundaries of accounting (Gambling, 1974; Estes, 1976, Gambling, 1978; Perks, 1993; Mathews, 1994, 1995; Gray et al., 1996; Gray and Bebbington, 2001). A considerable body of literature now exists which relates accounting to questions of economic growth and its links to social justice and development. In general, one can safely conclude that accounting plays a crucial supporting role in the construction and upholding of an economic order (Hines, 1988; Hopwood and Miller, 1994) and that SEA can lead to a new world where profits are not the sole focus of life (Lehman, 2001).

Figure 1 presents the elements that make up the conventional accounting in juxtaposition to those of SEA. It illustrates the inclusion of externalities and the perceived need to report other than economic events to groups additional to those addressed at present. It also epitomizes the current failure of financial accounting and reporting in recognizing its extensive social, economic, political and environmental connotations. By failing to include SEA, the implied values of conventional accounting can be questioned. Rather than accountability in the broader sense, conventional accounting is restricted to decision-usefulness and for a constrained scope of users.

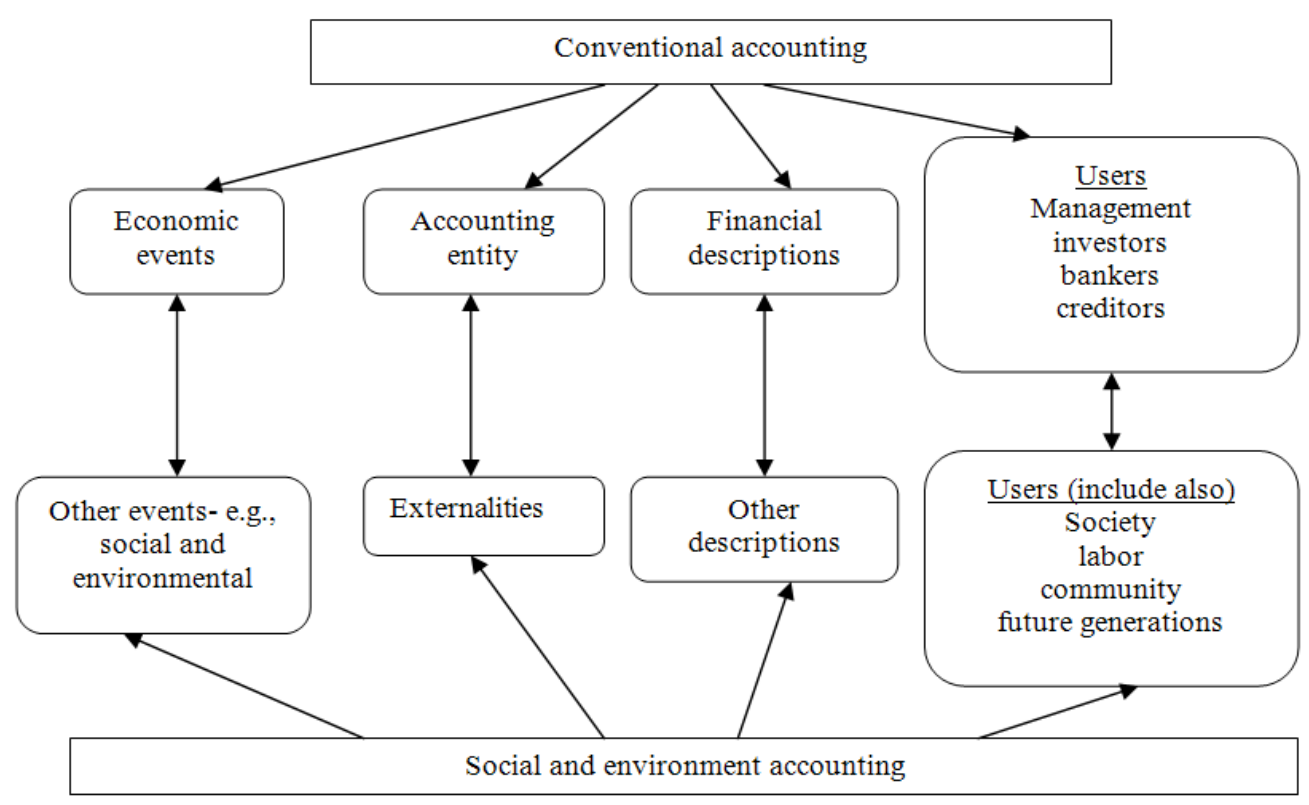

Fig. 1: Elements in conventional accounting and SEA adapted from Gray (1991, p.5) 


\section{MATERIALS AND METHODS}

Accounting academia serves a reasonably welldefined profession hence the education programs in the field normally are responsive to the changing demands placed on the accounting professionals (Frederickson and Pratt, 1995). For the purpose of this study, perceptions and views of accounting educators are identified in understanding and realizing the role that accounting education can play pertaining to aspects of social and environmental responsibility. The accounting educators comprise those who teach any accounting courses/subjects in the Malaysian Institution of Higher Learning (IHL). These institutions include the public and private universities, foreign branch university campuses and private/university colleges. Survey questionnaires are used to encompass a sufficiently broad coverage and to confirm the points under investigation. Several questionnaires used by previous studies that have a relation to SEA education have been adapted and they included those of Owen et al. (1994) and Gray et al. (2001). The sample size of the accounting educators is shown in Table 1. Practically, all of the questionnaires were mailed with a selfstamped return envelope. The contact addresses of the educators were obtained mostly from the prospectuses of the IHL and the Internet while some of them were found through telephone calls and personal contacts.

The respondents were all of an accounting background in terms of their education-either with a degree, masters and/or professional qualification. Since the informants are the products of the education, the feedback and perceptions that they provide on the research matter could reflect their orientation as accounting students either to their profession or in general. This point is crucial as the aim of the study is to seek the perceptions of educators, who have had the experience of undergoing accounting education or training. It is an accepted fact that the working environment and the maturity of respondents may have an impact on their perceptions and attitudes (McCollum, 2006).

The internal consistency of the survey instrument was measured by using Cronbach's coefficient alpha statistical test that provided an indication of the average correlation among all the items that made up the scale. The results (Table 2) demonstrated that all indices obtained were considered high (above .70). A sample scale that shows alpha value above .70 is considered reliable (Nunnally, 1978; Pallant, 2001), even though Bryman and Cramer (2001) prefer a higher scale with a minimum of 0.8 . Therefore, the indices for questionnaire reliability were generally considered adequate for this research.
Table 1: Sampling technique and sample size of accounting educators Type of respondents Accounting Educators

Sampling unit Accounting educators in the IHL Population estimates $\quad 1,500$

Sampling techniques Random and convenience sampling Sample size of respondents $\quad 800$

Table 2: Results of reliability test

\begin{tabular}{|c|c|c|c|}
\hline \multirow[b]{2}{*}{ Variables (total scores) } & \multirow{2}{*}{$\begin{array}{l}\mathrm{N} \text { of items } \\
\text { (questionnaire) }\end{array}$} & \multicolumn{2}{|c|}{ Cronbach's alpha } \\
\hline & & Educator & Practitioner \\
\hline Relevance of SEA education & 8 & 0.760 & 0.784 \\
\hline Roles of SEA education & 10 & 0.893 & 0.886 \\
\hline $\begin{array}{l}\text { Orientation of accounting } \\
\text { education }\end{array}$ & 17 & 0.763 & 0.783 \\
\hline
\end{tabular}

Table 3:Results on response/non-response bias using Kruskal-Wallis statistical test

\begin{tabular}{lll}
\hline & Time phase of questionnaires received \\
Variables (groups) & Chi-Square & Asymp. Sig. \\
\hline Relevance of SEA education & 0.268 & 0.875 \\
Roles of SEA education & 1.225 & 0.542 \\
Accounting education orientation & 1.943 & 0.379 \\
\hline
\end{tabular}

In analyzing the response/non-response bias issue, the Kruskal-Wallis Test was used because the data involved three phases of time referring to the dates the questionnaires were returned and ordinal measurements used for the variables. The test was conducted on the early and late responses (Wallace and Cooke, 1990) for the academics. The outcomes of the two-tailed test (Table 3) demonstrated that none of the six groups of variables tested for educators produced statistically significant results $(p<0.05)$ between the early and late return. Based on the above mentioned outcomes, it can be concluded that, to a statistically significant extent, the responses were the same whether they were returned earliest, later or latest. Therefore, judging from the Kruskal-Wallis Test, the 222 total responses could be merged and considered as one single population for the purpose of statistically analyzing the data and drawing conclusions from the summary statistics.

From the 800 questionnaires distributed to educators in Malaysia by mail, 222 of them were subsequently returned. The overall response rate (Table 4) was $27.7 \%$. By way of comparison it is worth highlighting the response rates achieved by other research works conducted with accountants or accounting related personnel in Malaysia. A study by on Malaysian accountants and environmental management reported a response rate of $28.0 \%$ out of 150 questionnaires that were sent out. It would appear that the overall response rate of accounting educators for the present study at $27.7 \%$ was comparable to those of previous studies, albeit they were more of accounting practitioners rather than accounting educators. 
Table 4: Response rates of accounting educators

\begin{tabular}{ll}
\hline Type of respondents & Accounting educators \\
\hline Sampling unit & Accounting educators in the IHL \\
Number of questionnaires sent & 800 \\
Number of questionnaires returned & 222 \\
Response rates & $27.7 \%$ \\
\hline
\end{tabular}

\section{RESULTS}

Overall, it is noted that the study focuses on the results of respondents and reflections on matters pertaining to SEA education and accounting education orientation. Brief profile of survey respondents is presented followed by the demonstration of the educators' perceptions towards the relevance and roles of SEA education as well the orientation of accounting education. Of the total (Table 5), female respondents (61.5\%) which exceed male respondents (38.5\%) shows that in Malaysia more females tend to be educators in the IHL compared to male.

Table 6 demonstrates that the majority of the respondents are represented by Muslims (89.1\%) followed by Christians (2.3\%), Buddhists (4.5\%), Hindus (2.3\%), other followers (0.4\%) and people with no religion (1.4\%). Malaysia has a multi-racial population, which consists of approximately 50\% Malays who are Muslims, 24\% Chinese who are mostly Buddhists and 7\% Indians who are mostly Hindus. The rest of the population comprises mainly of people from the other ethnic groups, such as the Dayaks and Kadazans. They originate from the two East Malaysian states of Sabah and Sarawak. The large number of Muslim respondents is a reflection of the relatively larger number of Malay accounting educators in the IHL. Since this study adopts the convenience and random sampling approach, it is unavoidable that more Malays are included in the sample as compared to other races.

Of the total number of respondents who indicated their years of working experience (Table 7), the most number of respondents have 5-10 years of working experience. This is followed by those with more than 10 years and lastly, by the most junior with less than 5 years. Of the total 222 cases, two respondents did not disclose their years of working experience. The higher concentration of the respondents in the 5-10 years group may indicate that SEA is new but increasingly being practiced or considered by accounting educators in the country. Thus, assuming that this group consists of the relatively younger generation, SEA seems to attract the interest of this group of educators. From the sample also (Table 8), it can be seen that the educators are attached to different types of IHL.
Table 5: Gender of respondents

\begin{tabular}{lcr}
\hline Gender & Accounting educator & $(\%)$ \\
\hline Male & 85 & 38.5 \\
Female & 136 & 61.5 \\
Total & 221 & 100.0 \\
\hline
\end{tabular}

*: One respondent did not reveal his or her gender

Table 6: Religion and nationality of respondents

\begin{tabular}{lrr}
\hline Religion and nationality & Accounting educators & (\%) \\
\hline Islam & 196 & 89.1 \\
Christianity & 5 & 2.3 \\
Buddhism & 10 & 4.5 \\
Hinduism & 5 & 2.3 \\
None & 3 & 1.4 \\
Other Religion & 1 & 0.4 \\
Total & 220 & 100.0 \\
Malaysian & 217 & 98.2 \\
Non-Malaysian & 4 & 1.8 \\
Total & 221 & 100.0 \\
\hline
\end{tabular}

*: Two respondents did not reveal their religion and one respondent did not reveal their nationality.

Table 7: Years of working experience of respondents

\begin{tabular}{lcc}
\hline Years of working experience & Accounting educators & (\%) \\
\hline Less than 5 years & 68 & 30.9 \\
5 to 10 years & 83 & 37.7 \\
More than 10 years & 69 & 31.4 \\
Total & 220 & 100 \\
\hline
\end{tabular}

*: Two respondents did not reveal their years of working experience

Table 8: Type of IHL (affiliation of respondents)

\begin{tabular}{lrr}
\hline Type of organizations/IHL & Accounting educators & (\%) \\
\hline Public university & 174 & 78.4 \\
Private university & 21 & 9.5 \\
Private college & 20 & 9.0 \\
Foreign university branch campus & 5 & 2.3 \\
Other types & 2 & 0.8 \\
Total & 222 & 100.0 \\
\hline
\end{tabular}

*: One respondent did not reveal the type of IHL or his/her organization

The larger representation of educator respondents from the public universities is attributable to the difficulty in securing a longer list of accounting educators from the other private IHL. In addition, the selection of the respondents was mainly from the established IHL. It is believed that in general, the accounting educators in those IHL have relatively vast experiences in teaching and research works.

Two groups of questions that specifically addressed aspects of SEA education were constructed. In the first group, eight statements were outlined that focused on the relevance of SEA education. In the second group, ten statements derived from the instruments of previous studies (Owen et al., 1994; Gray et al., 2001; Stevenson, 2002) were listed to understand the respondents' stance on the possible roles of SEA education. For both group of questions, the respondents were required to indicate their views from 
1 (strongly disagree) to 7 (strongly agree) on the eighteen individual statements. The results of their inputs are demonstrated in Table 9 for the two total groups of statements, in Table 10 for each statement on the relevance of SEA education and in Table 11 for each statement on the roles of SEA education.

Statements on the relevance of SEA education include the need for SEA education by the accounting profession, the benefits of SEA education such as in developing intellectual ability and ethical awareness of accounting students, the suitability of SEA to the accounting profession and the extent of values instilled in accounting teaching. The statements on the possible roles of SEA education include the enhancement of awareness of corporate social and environmental obligations and the exploration into the socially constructed nature of accounting practices to highlight the limitations of neo-classical economics.

As shown in table 9, the inputs from the educators result in total median and mode scores of 47.00 and 48.00 for the relevance of SEA education and, both 60.00 for roles of SEA education. Overall, the results imply that $50 \%$ of the educators tend to agree that SEA education is relevant and that it has roles to play either in tackling the issues of social and environmental problems to be specific hence sustainability or in overseeing the agenda of accounting education. Most frequently, educators agree with the relevance of SEA education. The respondents seem to indicate that they most frequently agree with the roles of SEA education. Based on the median score of each item (table 10), it is evident that half of the educators tend to agree with the statements on the relevance of SEA education.

The fact that the respondents slightly agree that accounting education instills values of social and environmental responsibility (median of 5.00), shows that there is a need for SEA education as traditionally accounting education is reported to be inadequate in producing professionals who are ethical. Despite mostly agreeing with the statements describing the relevance of SEA education as explained by the above results of median and mode, more than $10 \%$ of the respondents (Table 11) either is in disagreement with or is unsure of three items.

Table 9: Views of educators on SEA education (total group scores)

\begin{tabular}{|c|c|c|c|}
\hline \multirow{2}{*}{$\begin{array}{l}\text { Relevance and roles of } \\
\text { SEA education }\end{array}$} & \multicolumn{3}{|c|}{ Educators $(n=222)$} \\
\hline & Median & Mode & Mean rank \\
\hline Relevance of SEA education* & 47.00 & 48.00 & 270.44 \\
\hline Roles of SEA education** & 60.00 & 60.00 & 259.11 \\
\hline
\end{tabular}

Scale; 1-strongly disagree, 7- strongly agree; Variables range: *: $\min =8, \max =56 ; * *$ : $\min =10, \max =70 ; * *$

Table 10: Views of respondents on the relevance of SEA education

\begin{tabular}{|c|c|c|}
\hline \multirow[b]{2}{*}{$\begin{array}{l}\text { Please indicate your view on the following statements about Social and Environmental } \\
\text { Accounting (SEA) education and issues relating to it. }\end{array}$} & \multicolumn{2}{|c|}{ Educators $(\mathrm{n}=222)$} \\
\hline & Median & Mode \\
\hline a) SEA education is necessary for accounting profession. & 6.00 & 6.00 \\
\hline b) SEA education could help in developing intellectual ability of accounting students. & 6.00 & 6.00 \\
\hline c) SEA education could help in developing moral/ethical awareness of accounting students. & 6.00 & 6.00 \\
\hline d) SEA education is inappropriate because it does not suit with the technical nature of accounting education. & 6.00 & 6.00 \\
\hline e) SEA education is inappropriate because it does not suit with the professional orientation of accounting & 6.00 & 6.00 \\
\hline f) The accounting courses that I learn instill values of social responsibility towards a wider society and the environment. & 5.00 & 5.00 \\
\hline $\begin{array}{l}\text { g)Accounting educators/practitioners should have a basic knowledge of the issues concerned in social and } \\
\text { environmental responsibility elements. }\end{array}$ & 6.00 & 6.00 \\
\hline $\begin{array}{l}\text { h) Social and environmental issues should be explicitly discussed as part of accounting practitioners' } \\
\text { education and training. }\end{array}$ & 6.00 & 6.00 \\
\hline
\end{tabular}

Scale: 1-strongly disagree: 2-disagree: 3-slightly disagree: 4- neither agree nor disagree: 5- slightly agree: 6-agree: 7- strongly agree;

Table 11: Views of respondents on the relevance of SEA education (percentages)

\begin{tabular}{|c|c|c|c|}
\hline \multirow[b]{2}{*}{ Relevance of SEA education } & \multicolumn{3}{|c|}{ Educators $(\mathrm{n}=222)$} \\
\hline & Agree & Neutral & Disagree \\
\hline Necessary for accounting profession & 97.3 & 2.7 & - \\
\hline Could develop intellectual ability of students & 93.1 & 5.0 & 1.9 \\
\hline Could develop moral/ethical awareness & 96.8 & 1.8 & 1.4 \\
\hline Suits with technical nature & 81.0 & 10.4 & 8.6 \\
\hline Suits with professional orientation & 81.9 & 8.6 & 9.5 \\
\hline Instill values of social and environmental responsibility in current teaching/learning & 72.1 & 10.5 & 17.4 \\
\hline Basic knowledge is essential & 96.3 & 2.7 & 1.0 \\
\hline Should be discussed explicitly in training and education & 96.3 & 2.3 & 1.4 \\
\hline
\end{tabular}


The three items refer to the suitability of SEA education with the technical nature of accounting (19\%), the suitability of SEA education with the professional orientation (18.1\%) and the instilling of the values of social and environmental responsibility by current accounting education $27.9 \%$ ).

The results as illustrated in Table 12 reveal that half of the respondents tend to agree (median of 6.00) with all the statements pertaining to the roles of SEA education. Most frequently (mode of 6.00), the respondents appear to agree with all the roles of SEA education. In terms of percentages (Table 13), more than $10 \%$ of the respondents are shown to be either neutral or in disagreement with five instances. These include; criticize nature of society (15.9\%), apply accounting in non-financial areas (11\%), highlight limitations in neo-classical economy $(22.9 \%)$ and fill a gap in accounting education (13.1\%). Based on the findings about the roles of SEA education, it can be safely concluded that this study corroborates the findings of earlier studies by Owen et al. (1994) and Gray et al. (2001) concerning the perception of the respondents on SEA teaching in that it primarily enhances the awareness of students on the social and environmental obligations of corporations. As indicated by the statistics, a large percentage of the educators (99.5\%) concur with the above statement. In addition, $97.2 \%$ of the educators agree with the statement that a subsidiary aim of SEA education is to enhance the students' awareness of the economic and social consequences of accounting. This finding too, is in line with that of previous studies.

Apart from the statements with regards to the relevance and roles of SEA and SEA education, seventeen statements reflecting various characteristics and issues of accounting education orientation that have a bearing on SEA were established in the questionnaire (Blundell and Booth, 1988; Owen et al., 1994; Collison et al., 2000; Gray et al., 2001; Stevenson, 2002 and others for their discussions on SEA education and accounting education approach). For the purposes of analysis, these seventeen statements were categorized into eight groups, namely professional influences, leadership, technical orientation, critical and intellectual thinking, social skills and concern for public interest, Neo-classical criteria, nonconventional elements and, ethical and moral issues.

Table 12: Views of respondents on the possible roles of SEA education

\begin{tabular}{lc} 
Please indicate your view on the possible roles of social and environmental accounting education & Educators (n=222) \\
as stated in the following statements. Social and environmental accounting could & Median \\
\hline Enhance students' awareness of the social and environmental obligations of corporate behavior. & 6.00 \\
Enhance students' awareness of recent developments on critical accounting theory. & 6.00 \\
Explore the socially constructed nature of accounting practices. & 6.00 \\
Study the economic and social consequences of accounting. & 6.00 \\
Criticize the nature of society and the dominant interest being served. & 6.00 \\
Illustrate the scope for applying accounting calculations in traditionally non-financial areas. & 6.00 \\
Highlight the limitations of neo-classical economics as an underpinning of the accounting craft. & 6.00 \\
Facilitate the development of improved ways of accounting in organizations. & 6.00 \\
Fill a gap in students' accounting education. & 6.00 \\
Teach material that better reflects the political and social beliefs of academic accounting staff. & 6.00 \\
\hline
\end{tabular}

Scale: 1-strongly disagree: 2-disagree: 3-slightly disagree: 4- neither agree nor disagree: 5-slightly agree: 6-agree: 7- strongly agree; *: Significant at $5 \%$ level; **: significant at $1 \%$ level; n/s- non-significant

Table 13: Views of respondents on the roles of SEA education (percentages)

\begin{tabular}{|c|c|c|c|}
\hline \multirow[b]{2}{*}{ Roles of SEA education } & \multicolumn{3}{|c|}{ Educators $(\mathrm{n}=222)$} \\
\hline & Agree & Neutral & Disagree \\
\hline Enhance awareness of social environmental obligations. & 99.5 & 0.5 & - \\
\hline Enhance awareness of critical accounting theory. & 94.9 & 3.2 & 1.9 \\
\hline Explore socially constructed nature of accounting policies. & 94.6 & 4.5 & 0.9 \\
\hline Economic and social consequences of accounting. & 97.2 & 2.3 & 0.5 \\
\hline Criticize nature of society. & 84.1 & 10.4 & 5.5 \\
\hline Apply accounting in non- financial areas. & 89.0 & 8.6 & 2.4 \\
\hline Highlight limitations of neo-classical economy. & 77.1 & 20.5 & 2.4 \\
\hline Develop improved ways of accounting. & 91.8 & 6.3 & 1.9 \\
\hline Fill a gap in accounting education. & 86.9 & 9.0 & 4.1 \\
\hline Teach materials of social and political. & 84.8 & 11.5 & 3.7 \\
\hline
\end{tabular}


Table 14: Views of respondents on orientation of accounting education

\begin{tabular}{|c|c|c|c|}
\hline \multirow[b]{2}{*}{ Accounting education: } & \multicolumn{2}{|c|}{ Educators $(\mathrm{n}=222)$} & \multirow{2}{*}{$\begin{array}{l}\text { Percentage } \\
\text { (agreeing) }\end{array}$} \\
\hline & Median & Mode & \\
\hline \multicolumn{4}{|l|}{ Professional influenced, leadership and technical in orientation } \\
\hline Is very much influenced by the professional bodies. & 6.00 & 6.00 & 94 \\
\hline Trains students for leadership & 5.00 & 5.00 & 69 \\
\hline Provides syllabus which is technical in orientation. & 6.00 & 6.00 & 92 \\
\hline \multicolumn{4}{|l|}{ Critical and intellectual thinking } \\
\hline Encourages critical thinking & 6.00 & 6.00 & 89 \\
\hline $\begin{array}{l}\text { Provides curriculum which encourages the development of student's } \\
\text { intellectual ability. }\end{array}$ & 5.00 & 6.00 & 79 \\
\hline \multicolumn{4}{|l|}{ Social skills and concern for public interest } \\
\hline Prepares graduates with social skills required by employers. & 5.00 & 6.00 & 67 \\
\hline Teaches students to serve public interest. & 5.00 & 6.00 & 67 \\
\hline \multicolumn{4}{|l|}{ Neo-classical criteria } \\
\hline Instills self-interest elements. & 5.00 & 6.00 & 62 \\
\hline Does not instill profit maximization elements. & $5.00 \mathrm{R}(3.00)$ & 5.00R (3.00) & 51 \\
\hline Provides syllabus which is too concerned with the economic growth. & 5.00 & 6.00 & 54 \\
\hline \multicolumn{4}{|l|}{ Non-conventional elements } \\
\hline Is concerned with the link between economic growth and social justice. & 6.00 & 6.00 & 88 \\
\hline $\begin{array}{l}\text { Should consider a wider concept of accountability than the traditional view } \\
\text { of financial accountability to shareholders only. }\end{array}$ & 6.00 & 6.00 & 95 \\
\hline \multicolumn{4}{|l|}{ Ethics and moral issues } \\
\hline Does not provide clear teaching on moral, politics and social issues. & $3.00 \mathrm{R}(5.00)$ & 3.00R (5.00) & 27 \\
\hline Encourages sufficient ethical development. & 5.00 & 5.00 & 60 \\
\hline $\begin{array}{l}\text { Accounting practitioners' ethical behaviors can be influenced by accounting } \\
\text { teaching in the higher learning institution. }\end{array}$ & 6.00 & 6.00 & 90 \\
\hline $\begin{array}{l}\text { Changes in the accounting curriculum should be made if accounting education } \\
\text { is to emphasize a moral dimension. }\end{array}$ & 6.00 & 6.00 & 95 \\
\hline $\begin{array}{l}\text { Religious studies could help in developing the moral behavior of } \\
\text { accounting students. }\end{array}$ & 7.00 & 7.00 & 91 \\
\hline
\end{tabular}

Scale: 1-strongly disagree: 2-disagree: 3-slightly disagree: 4- neither agree nor disagree: 5- slightly agree: 6-agree: 7- strongly agree;

For this survey, the respondents were required to indicate their levels of agreement (1- strongly disagree: 7- strongly agree) as to whether accounting education can be attributed to the criteria listed above.

The results of the respondents' views on the orientation of accounting education (Table 14) suggest a number of points. In general, the perceptions of the accounting educators on all aspects of accounting education orientation are not reflective of the inadequate picture of accounting education as provided in the literature. It appears that there is a sense of either positive outlook or uncertainty about some of the assertions leveled at accounting education. Despite the rather depressing views towards accounting education in the literature, it would appear that accounting education in Malaysia is marked by a sense of relative uncertainty when viewed against the criteria used in the survey. It is also pertinent to note that this uncertainty in no way precludes the relevance of SEA as borne by the feedback from the respondents. Among the statements (Table 14), the least number of educators (27\%) seem to agree with the statement that accounting education does not provide clear teaching on moral, politics and social issues. A capital $\mathrm{R}$ indicates that this statement has been re-coded from a negative to a positive sentence. The figures in brackets are the percentages if the negative sentence had remained unchanged. A relatively small percentage of the educators (60\%) are found to be in agreement with the statement that accounting education encourages sufficient ethical development. For the other three statements (o, p, q) concerning accounting teaching, change of curriculum and religious values, the percentage of educators who agree is large at an average of approximately $92 \%$.

As shown in Table 14, median scores of 6.00 (agree) are recorded for the educators for two orientation criteria: professional influences and technical.

This means that half of the respondents agree with the two criteria. As shown also, half of the respondents agree (median of 6.00) that accounting education encourages critical thinking. Based on mode scores, it is evident that they frequently agree with the two aspects of accounting education orientation.

As can be seen, half of them slightly agree (median of 5.00) that accounting education prepares graduates with social skills and teaches them to serve the public 
interest. However, most frequently, they appear to agree (mode of 6.00) that accounting education does prepare graduates with social skills. In the case of the later criteria, the educators most frequently agree (mode of 6.00) that accounting teaches students to serve the public interest

Based on the median scores, $50 \%$ of the respondents appear to agree slightly (median of 5.00) that accounting education instills self-interest elements and that it is too concerned with economic growth. It is worth noting that this particular statement was worded negatively in the questionnaire, but was subsequently converted to a positive mode by the SPSS for the purpose of analysis. In both situations, the results appear to be similar. In terms of percentages, overall, slightly more than $50 \%$ of the respondents agree with the three criteria of neo-classical accounting education orientation. In addition, the results indicate that the respondents are divided on the question of whether education orientation adheres to the neo-classical criteria (i, s, j). Similar to the explanation given above, the figures with capital $\mathrm{R}$ denote that they were recoded from a negative to a positive mode of sentences. Two statements describing non-conventional elements of accounting were included in the questionnaire. The respondents were asked to indicate their agreements as to whether accounting education is concerned with the link between economic growth and the development of social justice and whether accounting education should consider a wider concept of accountability. These statements reflect elements of SEA in the accounting education orientation. The results reveal that $50 \%$ of respondents agree (median of 6.00) to the two statements mentioned above. At the same time, they agree most frequently (mode of 6.00) that accounting education addresses or should address the two nonconventional criteria.

Table 14 also demonstrates the results of the five statements pertaining to the teaching of ethics and morals in accounting education. The responses indicate median scores of (3.00, 5.00 and 6.00) for all statements, except for the last item. In this case, half of the educators strongly agree (median of 7.00) that moral behavior of accounting students can be developed through religious studies. On the statement that accounting education provides clear teaching on moral, politics and social issues, $50 \%$ of the respondents indicate that they only slightly disagree (3.00). This particular statement was worded negatively in the questionnaire and was re-coded and worded positively. Apart from the strong opinions on religious studies (median of 7.00 ), $50 \%$ of the respondents agree that the behaviors of accountants and auditors can be influenced by accounting education (median of 6.00) and that accounting syllabus should be changed to emphasize the moral dimension (median of 6.00). Half of them also slightly agree (5.00) that accounting education encourages sufficient ethical development. As indicated by the mode scores, most frequently the respondents slightly agree (5.00) that accounting education encourages sufficient ethical development. The scores also suggest that they agree most of the time (6.00) that the ethical behaviors of accountants/auditors can be influenced by accounting education and that accounting syllabus should be changed to emphasize the moral dimension.

In general, the perceptions of the accounting educators on all aspects of accounting education orientation are not reflective of the inadequate picture of accounting education as provided in the literature. It appears that there is a sense of either positive outlook or uncertainty about some of the assertions leveled at accounting education. Despite the rather depressing views towards accounting education in the literature, it would appear that accounting education in Malaysia is marked by a sense of relative uncertainty when viewed against the criteria used in the survey. It is also pertinent to note that this uncertainty in no way precludes the relevance of SEA as borne by the feedback from the respondents.

\section{DISCUSSION}

The results shown thus far indicate that the accounting educators appear to accept positively the general idea and concepts underlying SEA, with the one exception being the nebulous issue of accounting measurement. On the relevance and roles of SEA, the overall impression from the survey suggests that the respondents perceive them in a positive light. However, despite viewing positively the roles of SEA education, a relatively large percentage of the accounting educators do not appear to agree on the following roles: Criticize nature of society, apply accounting in non-financial areas, highlight the limitations of neo-classical economy, fill a gap in accounting education and teach social and political materials. In addition, the majority of the accounting educators seem to agree that SEA education can develop improved ways of accounting. The eight criteria of accounting education orientation invoked positive responses from the educators. It appears that the respondents agree or partly agree with 
most of them, with the exception of the criterion that says accounting education provides clear teaching on moral, politics and social issues. Another finding suggests that a large number of accounting educators appear to agree that moral behavior of accounting students could be developed through religious studies.

This study may pave the way for the development of SEA education framework as a vehicle for further discussions on the accounting curriculum. It recognizes the positive reception by the Malaysian accounting educators to the elements embodied by SEA and the affinity between the values expounded by SEA and those of religious values such as Islam. It postulates the strong likelihood that SEA, Corporate Social Disclosure (CSD) and SEA education will take root in Malaysia given the strong undercurrents of accounting and business malpractices and the clarion call by many for the reinstatement of the ethical dimension of the profession. It advocates a formal approach of SEA education in the IHL as the appropriate means of enhancing social and environmental awareness and the inculcation of ethical values. It is imperative that the education curriculum now considers even more the learning of management, communication and analytical skills (among others, Albrecht and Sack, 2001).

Other important areas include business finance, strategy and information management and cognitive skills. Overall, the main aim is to enable the accountants to provide more value-added services and ensure that the process for delivery of service is efficient and effective or else other service providers such as fund managers, financial analysts and information technology specialists might make inroads into the profession. Despite the above developments and the proliferation of environmental problems, (Zakaria et al., 2010) it appears that matters relating to the education on social, environmental and ethical issues have yet to be expressly included as part of any agenda or part of the major professional issues or the curriculum of the various accounting programs. It is therefore timely that studies are conducted to explore the state of affairs of SEA and ethics in the Malaysian accounting education system.

Despite the minimal existence of SEA education in Malaysia and the uncertain reactions of accounting educators to the adverse effects of accounting education orientation, arguably learning and understanding SEA is imperative for reasons that go beyond the adequacy or lack thereof of current accounting education. The increase in social and environmental ills resulting from the encroachment by businesses is enough justification by itself (Bataineh, 2006). The non-conventional elements of SEA and its adherence to noble values that are compounded with religious undertones are essential for the accounting students and the practitioners in order to confront organization's agenda towards the society and the environment and ultimately the sustainability issue (Burritt and Schltegger, 2010; Murad et al., 2008). The results of the study indicate that accounting educators in Malaysia are receptive towards the idea of SEA accounting education as a means towards confronting the social and environmental problems which in part could be due to unethical business and accounting practices. They perceive that teaching accounting the non-conventional way which is through SEA is relevant although they consider that some of the elements embedded in SEA especially the issue of accounting measurement are to be resolvedIn essence, apart from overseeing the accounting practices so that they could give a positive impact towards the issue of sustainability, it is imperative to consider tackling the social and environmental agenda through accounting education.

\section{CONCLUSION}

On the relevance and roles of SEA, the overall impression from the survey suggests that the respondents perceive them in a positive light. However, despite viewing positively the roles of SEA education, a relatively large percentage of the accounting educators do not appear to agree on the following roles: criticize nature of society, apply accounting in non-financial areas, highlight the limitations of neo-classical economy, fill a gap in accounting education and teach social and political materials. The results also indicate that the majority of the accounting educators seem to agree that SEA education can develop improved ways of accounting. The eight criteria of accounting education orientation invoked positive responses from the educators. It appears that the respondents agree or partly agree with most of them, with the exception of the criterion that says accounting education provides clear teaching on moral, politics and social issues. Another finding suggests that a large number of accounting educators appear to agree that moral behavior of accounting students could be developed through religious studies.

\section{REFERENCES}

Accounting Education Change Commission, 1990. AECC urges priority for teaching in higher education. Issues Account. Educ., 5: 330-31. 
Albrecht, W.S. and R.J. Sack, 2000. Accounting education: Charting the course through a perilous future. American Accounting Association, USA., ISBN: 0-86539-088-6, pp: 72.

Albrecht, W.S. and R.J. Sack, 2001. The perilous future of accounting education. CPA J., 71: 16-23.

Al-Rabaani, A.B.H. and S.S.M. Al-Mekhlafi, 2009. Attitudes of sultan qaboos university students towards some environmental problems and their willingness to take action to reduce them. J. Soc. Sci., 5: 9-15. DOI: 10.3844/jssp.2009.9.15

Bataineh, T.M., 2006. The role of an environmental management in improving of competition in manufacturing companies. J. Soc. Sci., 2: 48-53. DOI: $10.3844 /$ jssp.2006.48.53

Bebbington, J., 1995. Teaching social and environmental accounting: A review essay. Account. Forum, 19: 263-273.

Bebbington, J., 1997. Engagement, education and sustainability: A review essay on environmental accounting. Account., Audit. Account. J., 10: 365-381.

Bebbington, J., 2001. Sustainable development: A review of the international development, business and accounting literature. Account. Forum, 25: 128-158.

Bloom, R. and H. Heymann, 1986. The concept of 'social accountability' in accounting literature. J. Account. Literat., 5: 167-182.

Blundell, L. and P. Booth, 1988. Teaching innovative accounting topics: Student reaction to a course in social accounting. Account. Finance, 28: 75-85.

Bryman, A. and D. Cramer, 2001. Quantitative Data Analysis with SPSS Release 10 for Windows: A Guide for Social Scientists. 1st Edn., Routledge, London, ISBN: 0415244005, pp: 320.

Burritt, R. and S. Schltegger, 2010. Sustainability accounting and reporting: fad or trend?, accounting. Audit. Account. J., 23: 829. ISSN: 09513574, DOI: 10.1108/09513571011080144

Churchman, C.W., 1971. On the facility, felicity and morality of measuring social change. Account. Rev., 46: 30-35.

Collison, D., R. Gray, D. Owen, D. Sinclair and L. Stevenson, 2000. Social and environmental accounting and student choice: An exploratory research note. Account. Forum, 24: 170-187.

Cooper, D.J. and M.J. Sherer, 1984. The value of corporate accounting reports: Arguments for a political economy of accounting. Account., Org. Soc., 9: 207-232.
Crowther, D., 2000. Social and Environmental Accounting. 1st Edn., Pearson Education Limited, London, ISBN: 0273650920, pp: 109.

Estes, R.W., 1976. Corporate Social Accounting. 1st Edn., John Wiley and Sons, New York, ISBN: 9780471245926, pp: 166.

Ferguson, J., D. Collison, D. Power and L. Stevenson, 2005. What are recommended accounting textbooks teaching students about corporate stakeholders?, Br. Account. Rev., 37: 23-46.

Frederickson, J.R. and J. Pratt, 1995. A model of the accounting education process. Issues Account. Educ., 10: 229-237.

Gambling, T., 1974. Societal Accounting. 1st Edn., George Allen and Unwin, London, ISBN: 9780043302422, pp: 228.

Gambling, T., 1978. Beyond the Conventions of Accounting. 1st Edn., McMillan Press, London, ISBN: 97803333189665, pp: 192.

Gibson, K., 1997. Notes Courses on environmental accounting. Account., Audit. Account. J., 10: 584-593.

Gray, R.H. and J. Bebbington, 2001. Accounting for the Environment. 1st Edn., Sage Publications, London, ISBN: $9781558760769, \mathrm{pp}: 348$.

Gray, R.H., 1991. The accountancy profession and the environmental crisis. Discussion study ACC/9102, University of Dundee.

Gray, R.H., D. Collison, J. French, K.J. McPhail and L. Stevenson, 2001. The Professional Accounting Bodies and the Provision of Education and Training in Relation to Environmental Issues. 1st Edn., The Institute of Chartered Accountants of Scotland, Scotland, ISBN: 1871250 897, pp: 220.

Gray, R.H., D. Owen and C. Adams, 1996. Accounting And Accountability: Changes and Challenges in Corporate Social and Environmental Reporting. 2nd Edn., Prentice Hall, Harlow, Essex, ISBN: 0131758608, pp: 344.

Gray, R.H., J. Bebbington and K. McPhail, 1994. Teaching ethics in accounting and the ethics of accounting teaching: Educating for immorality and a possible case for social and environmental accounting education. Account. Educ. Int. J., 3: 51-75.

Grinnel, D.J. and G.H. Hunt, 2000. Development of an integrated course in accounting: A focus on environmental issues. Issues Account. Educ., 15: 19-42.

Hines, R.D., 1988. Financial accounting: In communicating reality, we construct reality. Account., Org. Soc., 13: 251-61. 
Hopwood, A.G. and P. Miller, 1994. Accounting as Social and Institutional Practice. 1st Edn., Cambridge University Press, Cambridge, ISBN: 0521469651, pp: 340.

Huss, H.F. and D.M. Patterson, 1993. Ethics in accounting: Values education without indoctrination. J. Bus. Ethics, 12: 235-243.

Kelly, M., H. Davey and N. Haigh, 1999. Contemporary accounting education and society. Account. Educ. Int. J., 8: 321-340.

Lehman, G., 2001. Accounting millennium themes: Toward accounting in a steady-state. Account. Forum, 25: 211-214.

Lewis, L., C. Humphrey and D. Owen, 1992. Accounting and the social: A pedagogic perspective. Br. Account. Rev., 24: 219-233.

Linowes, D.F., 1972. Socio-economic accounting. J. Account., 133: 37-42.

Lockhart, J.A. and M.R. Mathews, 2000. Teaching environmental accounting: A four-part framework. Adv. Account. Educ. Teach. Curriculum Innovat., 3: 57-84.

Mahmood, H.K., 2002. When is economic growth propoor? Experiences in Malaysia and Pakistan. IMF Institute, http:www. Imf.org/external

Mathews, M.R. and Perera, M.H.B., 1996. Accounting Theory and Development. 3rd Edn., Thomas Nelson, Australia, ISBN: 0170091023, pp: 416.

Mathews, M.R., 1993. Socially Responsible Accounting. 1st Edn., Chapman and Hall, London, ISBN: 0412473402, pp: 240.

Mathews, M.R., 1994. A comment on lewis, Humphrey and Owen accounting and the social: A pedagogic Perspective. Br. Account. Rev., 26: 91-97.

Mathews, M.R., 1995. Social and environmental accounting: A practical demonstration of ethical concern?, J. Bus. Ethics, 14: 663-674.

McCollum, D., 2006. Student perceptions, beliefs, or attitudes: Editorial. Acad. Exc. Q., 10: 1-6.

Mobley, S.C., 1970. The challenges of socio-economic accounting. Account. Rev., 45: 762-768.

Murad, M.W., N.H.N. Mustapha and C. Siwar, 2008. Review of Malaysian agricultural policies with regards to sustainability. Am. J. Environ. Sci., 4: 608-614. DOI: 10.3844/.2008.608

Nunnally, J.O., 1978. Psychometric Theory. 2nd Edn., McGraw- Hill, New York, ISBN: 9780070474659, pp: 701.
Owen, D., 2004. Adventures in Social and Environmental Accounting and Auditing Research: A Personal Reflection. In: The Real Life Guide to Accounting Research, Humphrey, C. and B. Lee (Eds.). Elsevier Science, Oxford, ISBN: 9780080489926, pp: 23-36.

Owen, D.L., C. Humphrey and L. Lewis, 1994. Social and Environmental Accounting Education in British Universities. 1st Edn., The Chartered Association of Certified Accountants, London, ISBN-10: 1898291462, pp: 48.

Paisey, C. and N.J. Paisey, 2000. A Comparative Study of Undergraduate and Professional Education in the Professions of Accountancy, Medicine, Law and Architecture. 1st Edn., The Institute of Chartered Accountants of Scotland, Edinburgh, ISBN: 1871250838, pp: 167.

Pallant, J., 2001. SPSS Survival Manual: A Step by Step Guide to Data Analysis Using SPSS for Windows (Version 10). 1st Edn., Open University Press, Buckingham, ISBN: 0335208908, pp: 304.

Parker, D., 2005. Social and environmental accountability research: A view from the commentary box. Account. Audit. Account. J., 18: 842-860.

Perks, R.W., 1993. Accounting and Society. 1st Edn., Chapman and Hall, London, ISBN: 0412473305, pp: 272.

Seidler, L.J., 1975. Social Accounting: Theory, Issues and Cases. 1st Edn., Melville Publishing Company, California, ISBN: 047177488X, pp: 547.

Stevenson, L., 2002. Social and environmental accounting teaching in UK and Irish universities: A research note on changes between 1993 and 1998. Account. Educ. Int. J., 11: 331-346.

Tinker, A.M., 1980. Towards a political economy of accounting: An empirical illustration of the Cambridge controversies. Account. Org. Soc., 5: 147-160.

Tinker, T., 1991. The accountant as partisan. Account. Org. Soc., 16: 297-310.

United Nations World Commission on Environment and Development, 1987. Our Common Future. 1st Edn., Oxford University Press, Oxford, ISBN: 019282080X, pp: 400.

Wallace, R.S.O. and T.E. Cooke, 1990. Non-response bias in mail accounting surveys: A pedagogical extension. Br. Account. Rev., 22: 283-288.

Wyatt, A.R., 2004. Accounting professionalism-they just don't get it. Account. Horizons, 18: 45-54. 
Zakaria, Z., Zakaria, Z., N. Noordin and M.Z.M. Sawal, 2010. Environmental functions provided by malaysian local government: user's perception. J. Social Sci., 6: 296-302. DOI: 10.3844/jssp.2010.296.302
Zeff, S.A., 1989. Does accounting belong in the university curriculum? Issues Account. Educ., 4: 203-210. 